Ilmu Pertanian (Agricultural Science)

Vol. 1 No.2 August, 2016 : 062-066

Available online at http://journal.ugm.ac.id/jip

DOI: doi.org/10.22146/ipas.11341

ILMU PERTANIAN
(AGRICULTURAL SCIENCE)

\title{
Effect of The Substitution of Compound Fertilizer With Single Fertilizer and Mycorrhizal Inoculation on The Growth and Yield of Soybean Among Eucalyptus
}

\author{
Apresus Sinaga $^{1 *}$, Didik Indradewa ${ }^{1}$, Priyono Suryanto ${ }^{2}$ \\ ${ }^{1}$ Department of Agronomy, Faculty of Agriculture, Universitas Gadjah Mada \\ Jln. Flora no. 1, Bulaksumur, Sleman, Yogyakarta 5528, Indonesia \\ ${ }^{2}$ Faculty of Forestry, Universitas Gadjah Mada \\ Jln. Agro no. 1, Bulaksumur, Sleman, Yogyakarta 5528, Indonesia \\ *Corresponding email:apresusnaga@gmail.com
}

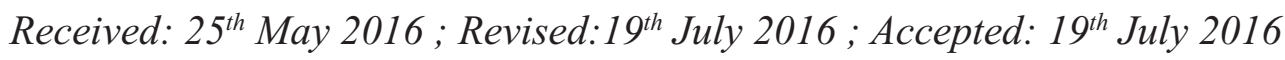

\begin{abstract}
The efforts to improve the productivity of soybean can be done through technological innovation by the provision of chemical fertilizers and mycorrhizae. This study were aimed to obtain information on the effect of a single fertilizer, which can provide the same or higher level of soybean crops if compared with those compound fertilizers, as well as to find out the effect of mycorrhizae to the improvement of efficiency in the use of inorganic fertilizers. It is expected that the mycorrhizae inoculation can reduce single fertilizer's dose to the level equivalent to the compound fertilizer given by farmers. The study was conducted in Bleberan Village, Playen Subdistrict, Gunung Kidul Regency, Yogyakarta from February to May 2015. It was conducted by using a two-factors factorial design arranged in a randomized block design with three replications. The first factor was inorganic fertilizer $\left(\mathrm{N}, \mathrm{P}_{2} \mathrm{O}_{5}\right.$ and $\left.\mathrm{K}_{2} \mathrm{O}\right)$, consisting of 5 levels, i.e. without fertilizer (0-0-0 kg ha-1), Phonska fertilizer (45-45-45 kg ha-1), single fertilizer (45-45-45 kg ha-1), a low single fertilizer (23-36-30 $\left.\mathrm{kg} \mathrm{ha}^{-1}\right)$ and high single fertilizer (23-108-90 $\left.\mathrm{kg} \mathrm{ha}^{-1}\right)$. The second factor was mycorrhizal inoculation, consisting of three levels, i.e. without mycorrhizae $(0 \mathrm{~g})$, medium dose $(2.5 \mathrm{~g})$ and high dose $(5 \mathrm{~g})$. Data were analyzed using Analysis of Variance (ANOVA) at a significance level of 5\%. If there was a significant difference, analysis was followed by Duncan Multiple Range Test with a significance level of 5\%. The relationship between variables observed was examined by a correlation analysis. The results showed that there was no interaction between inorganic fertilizer and mycorrhizal application. The dose of single fertilizer which was equivalent to the dose of compound fertilizer given to soybean could increase crops by $1.37 \mathrm{t} \mathrm{ha}^{-1}$ compared with plants treated with a compound fertilizer $1.13 \mathrm{t}$ ha${ }^{1}$. The results of correlation analysis among parameters showed that there were correlations between the grain crops and height $\left(\mathrm{r}=0.506^{* *}\right)$, stem diameter $\left(\mathrm{r}=0.303^{*}\right)$, and the number of pods per plant $\left(\mathrm{r}=0.313^{*}\right)$.
\end{abstract}

Keywords: Combination of Inorganic Fertilizers-Mycorrhizae, Crops, Soybean

\section{INTRODUCTION}

Soybean (Glycine max) is a major commodity crops in addition to paddy and maize (Oktaviani et al., 2014). Soybean plants are not only the source of protein, but also the important sources of fat, vitamins, and minerals for human being. Soybean plant is also the major source of protein for animal feeds, especially poultry.

Gunung Kidul communities are a group of farmers who cultivate eucalyptus on dry land. Besides eucalyptus, they cultivate soybeans among eucalyptus tree. Based on the structure and components of sites of the study, it is included into an early agro-forestry, because a horizontal space for a seasonal plant is more than $50 \%$. This can be seen from the effect of trees in making the area being shadowed, thus leading to effective cultivating areas (Suryanto et al., 2005). Soybean cultivation on dry land in Gunung Kidul Regency is done in the second rainy season from February to May. The development of soybean among the eucalyptus forests can be done regularly throughout the year because it is not hampered by eucalyptus canopy (Sudarmaji et al., 2013). Ordinary farmers give fertilizers for soybean crops in a form of compound fertilizers. Mete et al. (2015) reported that $\mathrm{N}, \mathrm{P}$, and $\mathrm{K}$ fertilizers can increase soybean yield. 
The compound fertilizers are much more practical than single fertilizer, but the balance of $\mathrm{N}: \mathrm{P}: \mathrm{K}$ nutrients (15:15:15) is not appropriate to meet the need for nutrients of soybean crop as legume crop that symbiosizes with root nodule bacteria in fixing the air nitrogen. The compound fertilizers are also more expensive. The saving of cost can be made by substituting the compound fertilizer with single fertilizers with the same dose. However, no information is available on th effect of this substitution in soybean yield. In addition, no information is available about whether the fertilizer doses given by farmers are optimal or not. The use of NPK compound fertilizers for soybean plants may be one of the underlying causes of low soybean yield in Gunung Kidul Regency. Soybean productivity in Gunung Kidul Regency is relatively low, ranging from 0.6 to 2.0 ton/ha while the national average is $1.29 \mathrm{ton} / \mathrm{ha}$ (Sudarmaji et al., 2013).

Results from several studies showed that the use of mycorrhizae could improve nutrient uptake. Guissou (2009) reported that the application of mycorrhizal fungi was able to increase the nutrient uptake of $\mathrm{N}, \mathrm{P}, \mathrm{K}$, and Mg. Mycorrhizal fungi are fungi that live symbiotically with plant roots and the colonization of roots by fungi provides benefits to host plants because mycorrhizal fungi can increase nutrient and water uptakes, and the host plants provides carbohydrates (carbon) resulted from photosynthesis (Cram and Dumroese, 2012).

The integrated provision of both chemical fertilizers and mycorrhizae can increase efficiency in the use of fertilizer and reduce the dose of chemical one (Simanungkalit, 2001). Mycorrhizae can act to increase soybean roots growth, so it is likely that the roots require the lower dose of fertilizer to achieve the same growth and crops. Mycorrhizal infection in plant can promote its growth and the ability to utilize the nutrients in the soil (Aldeman and Morton, 1986).

It is necessary to conduct a study for gaining the information on the effect of the use of single fertilizer that can provide the same or higher level of soybean yield if compared with those which are treated with the compound fertilizer, and the effect of the use of mycorrhizae which can improve efficiency in the use of single fertilizer. It is expected that the use of mycorrhizae can reduce the dose of single fertilizer with a dose equivalent to the dose of compound fertilizer given by farmers.

\section{MATERIALS AND METHODS}

\section{Procedures of the Study}

The study was conducted in Bleberan Village, Playen Subdistrict, Gunung Kidul Regency, Yogyakarta from February to May 2015. Materials of the study were soybean seeds of Grobogan variety, mycorrhiza, Phonska fertilizer of NPK (15:15:15), urea, SP-36, and $\mathrm{KCl}$. The study was conducted by using a $5 \times 3$ factorial design prepared with a randomized block design with three replications. The combination of inorganic fertilizer and mycorrhizae doses can be seen in Table 1.

The size of land used was $337.5 \mathrm{~m}^{2}$, consisting of 15 experimental plots with three replications. The size of experimental plots was $3 \mathrm{~m}$ in length and 2.50 $m$ in width. The determination of the size of experimental plots was based on the width of path among eucalyptus. On each side of the experimental plots, ditches were made of $40 \mathrm{~cm}$ in depth and $30 \mathrm{~cm}$ in width. Soybean planting was done by dibbling with a pointed stick in order to sow seeds with a spacing of $25 \mathrm{~cm} \times 35$ $\mathrm{cm}$ and the number of seeds was 2-3 seeds per hole. The mycorrhizae and fertilizer were used in accordance with the procedures of treatment and in a separate manner; all were given by a dibbling technique with a depth of $5 \mathrm{~cm}$. All mycorrhizae were given at first fertilization, while the treatment of fertilizer was given twice. The first fertilization was done when plants were three weeks after planting, i.e. $50 \%$ Phonska and 50\% urea, while SP-36 and $\mathrm{KCl}$ were given consecutively at the first fertilization. Supplementary fertilization of 50\% Phonska and $50 \%$ urea was done when the plants were five weeks old. Plants that did not grow, damaged, and dead were replaced when they were at one week old. Weeding was done by unplugging and using a small hoe. Pest and disease control was done chemically with dose and type of pesticide adjusted with the recommendation.

\section{Observations}

Data were collected for three sample plants per experiment plot. The observation of growth parameters was done at $9^{\text {th }}$ week after planting, while that of soybean crop components was done when the plants were 12 weeks after planting. The growth parameters observed were plant height and stem diameter, while the yield parameters observed were the number of pods per plant, weight of 100 seeds, and yield per hectare (tonnes).

The soybean pods were dried for 2-3 days. Seeds were cleaned, and water content was measured using 
Table 1. Combination of Inorganic Fertilizer Dose (N, P2O5, K2O) and Mycorrhizae

\begin{tabular}{|c|c|c|c|c|c|c|}
\hline \multirow[b]{3}{*}{ Doses } & \multicolumn{3}{|c|}{ Factor I } & \multicolumn{3}{|c|}{ Factor II } \\
\hline & \multicolumn{3}{|c|}{ Inorganic Fertilizer $\left(\mathrm{kg} \mathrm{ha}^{-1}\right)$} & \multicolumn{3}{|c|}{ Mycorrhizae (g.plant ${ }^{-1}$ ) } \\
\hline & $\mathrm{N}$ & $\mathrm{P}_{2} \mathrm{O}_{5}$ & $\mathrm{~K}_{2} \mathrm{O}$ & $\begin{array}{c}\text { Without } \\
(0) \\
(\mathrm{M} 0)\end{array}$ & $\begin{array}{c}\text { Moderate } \\
(2.5) \\
(\mathrm{M} 1)\end{array}$ & $\begin{array}{l}\text { High } \\
(5) \\
(\mathrm{M} 2)\end{array}$ \\
\hline Without (P0) & 0 & 0 & 0 & P0M0 & P0M1 & P0M2 \\
\hline Phonska by Farmers (P1) & 45 & 45 & 45 & P1M0 & P1M1 & $\mathrm{P} 1 \mathrm{M} 2$ \\
\hline Single Fertilizer by Farmers (P2) & 45 & 45 & 45 & $\mathrm{P} 2 \mathrm{M} 0$ & P2M1 & $\mathrm{P} 2 \mathrm{M} 2$ \\
\hline Low Single Fertilizer (P3) & 23 & 36 & 30 & P3M0 & P3M1 & P3M2 \\
\hline High Single Fertilizer (P4) & 23 & 108 & 90 & P4MO & P4M1 & P4M2 \\
\hline
\end{tabular}

a moisture tester. The observation of soybean yield per hectare was calculated by using a formula according to Sirappa \& Rieuwpassa (2010).

$$
\mathrm{H}=\frac{100 \%-\mathrm{ka} \%}{100 \%-14 \%} \times \frac{10000 \mathrm{xb}}{1}
$$

where, $\mathrm{H}$ : yield of dry seeds per hectare; I: plot area (m2); b: weight of air dried seeds on the plot area (g); ka: air dried seed moisture content at harvest plot determined by moisture tester; 10,000: plot area per ha $\left(\mathrm{m}^{2}\right)$.

\section{Data Analysis}

The data obtained from the observations were analyzed using analysis of variance (ANOVA) at a significance level of $5 \%$. If the ANOVA result showed F-statistics was $>$ F-table, it means that there was a significant difference between the treatments, therefore the analysis was followed-up by Duncan Multiple Range Test with a significance level of 5\%. Relationship between the variables observed was examined by a correlation analysis.

\section{RESULT AND DISCUSSION}

\section{Growth Parameters}

Table 2 showed that there was no interaction between fertilization and mycorrhizal inoculation on plant height and stem diameter. Mycorrhizal inoculation did not affect either the height or diameter of stem. Wangiyana (2007) reported that the use of leaf fertilizer and mycorrhizal inoculation also showed no significant difference in height of soybean plants of 7 weeks compared to plants without any treatments.

Table 2 also showed that fertilization did not affect the plant height, but could increase soybean stem diameter. Aziz et al. (2016) reported that the use of $\mathrm{P}_{2} \mathrm{O}_{5}$ fertilizer at $49 \mathrm{~kg} \mathrm{ha}^{-1}$ did not cause significant difference in plant height compared with the plants without any fertilizers. The substitution of compound Phonska with single fertilizer with various doses also did not affect the height and diameter of stem.

\section{Yield Parameters}

There was no interaction between fertilizer and mycorrhizal inoculation and the yield of soybean grown among eucalyptus stands. There was no effect of fertilization on the number of pods formed, but the effect of fertilization on the weight of 100 grains of seed was found (Table 3).

The use of a single fertilizer with a dose equivalent to the dose of Phonska given by farmers did not significantly increase the seed size. The use of Phonska as usually given by farmers, or a single fertilizer with low or high doses could significantly increase seed size (Table 3). Mandal et al. (2009) reported that the use of fertilizers $\mathrm{N}, \mathrm{P}$, and $\mathrm{K}$ for 70 days after planting could increase the weight of 1000 seeds compared to plants without any fertilizers.

The seed yield was affected by fertilization. The use of Phonska given by farmers actually did not significantly increase the seed yield (Table 3 ). The substitution of low doses single fertilizer also did not increase the seed yield. Soybean yield could increase when the high dose of single fertilizer was given or simply when a single fertilizer with a dose similar to the dose of Phonska given by farmers was used.

The number of pods and the weight of 100 seeds were not affected by the mycorrhizal inoculation, so that it did not affect seed yield. Muis et al. (2013) reported that the use of mycorrhizae did not cause a significant difference in the number of pods, the number of seeds, the weight of 100 seeds, and the weight of seeds per plant.

\section{Correlation between Parameters}

There was a relationship among seed yield and plant height and stem diameter (Table 4). The plants with better growth were shown by taller stem and larger diameter as well as higher number of seed yield. The seed yield of taller plants were higher because the plants formed more pods, but not larger seeds. Da-yong et al. (2012) showed that there was 
Table 2. Soybean Plant Height and Stem Diameter at 9 Weeks after Planting

\begin{tabular}{|c|c|c|}
\hline \multirow[b]{2}{*}{ Treatment } & Plant Height $(\mathrm{cm})$ & Stem Diameter $(\mathrm{cm})$ \\
\hline & $\begin{array}{c}9 \text { Weeks } \\
\text { after Planting }\end{array}$ & $\begin{array}{c}9 \text { Weeks } \\
\text { after Planting }\end{array}$ \\
\hline \multicolumn{3}{|c|}{ Inorganic Fertilizer $\left(\mathrm{N}, \mathrm{K}_{2} \mathrm{O}_{5}\right.$ and $\left.\mathrm{K}_{2} \mathrm{O}_{5}\right)\left(\mathrm{kg} \mathrm{ha}^{-1}\right)$} \\
\hline Without Treatment $(0-0-0)$ & $40.46 \mathrm{a}$ & $3.37 \mathrm{~b}$ \\
\hline Phonska by Farmers (45-45-45) & $42.48 \mathrm{a}$ & $3.76 \mathrm{a}$ \\
\hline Single Fertilizer by Farmers (45-45-45) & $44.21 \mathrm{a}$ & $3.94 \mathrm{a}$ \\
\hline Low Single Fertilizer (23-36-30) & $41.96 \mathrm{a}$ & $3.95 \mathrm{a}$ \\
\hline High Single Fertilizer (23-108-90) & $42.62 \mathrm{a}$ & $3.93 \mathrm{a}$ \\
\hline \multicolumn{3}{|l|}{ Mychoriza $\left(\right.$ g plant $\left.^{-1}\right)$} \\
\hline Without Treatment (0) & $42.61 \mathrm{a}$ & $3.78 \mathrm{a}$ \\
\hline Moderate $(2,5)$ & $42.89 \mathrm{a}$ & $3.88 \mathrm{a}$ \\
\hline $\operatorname{High}(5)$ & $41.53 \mathrm{a}$ & $3.72 \mathrm{a}$ \\
\hline Interaction & $(-)$ & $(-)$ \\
\hline$\overline{\mathrm{CV} \%}$ & 12.76 & 10.43 \\
\hline
\end{tabular}

Remarks: The values followed by the same letter were not different from DMRT 5\%

Table 3. Number of Pods per Plant, Weight of 100 Seeds and Weight of Seeds per Hectare at 12 Weeks after Planting

\begin{tabular}{|c|c|c|c|}
\hline Treatment & $\begin{array}{c}\text { Number of Pods } \\
\text { per Plant } \\
\text { (fruits) }\end{array}$ & $\begin{array}{l}\text { Weight of } 100 \text { Seeds } \\
\text { (Seeds) }\end{array}$ & $\begin{array}{l}\text { Crops } \\
\text { (t/ha) }\end{array}$ \\
\hline \multicolumn{4}{|c|}{ Inorganic Fertilizers $\left(\mathrm{N}, \mathrm{K}_{2} \mathrm{O}_{5}\right.$ dan $\left.\mathrm{K}_{2} \mathrm{O}_{5}\right)\left(\mathrm{kg} \mathrm{ha}^{-1}\right)$} \\
\hline Without Treatment $(0-0-0)$ & $15.62 \mathrm{a}$ & $16.35 \mathrm{~b}$ & $0.97 \mathrm{c}$ \\
\hline Phonska by Farmers (45-45-45) & $16.98 \mathrm{a}$ & 17.89 a & $1.13 \mathrm{bc}$ \\
\hline Single Fertilizer by Farmers $(45-45-45)$ & $16.36 \mathrm{a}$ & $16.96 \mathrm{ab}$ & $1.37 \mathrm{ab}$ \\
\hline Low Single Fertilizer (23-36-30) & 19.49 a & $17.48 \mathrm{a}$ & $1.07 \mathrm{bc}$ \\
\hline High Single Fertilizer (23-108-90) & $20.62 \mathrm{a}$ & $17.78 \mathrm{a}$ & $1.49 \mathrm{a}$ \\
\hline \multicolumn{4}{|l|}{ Mychoriza (g plant $\left.{ }^{-1}\right)$} \\
\hline Without treatment $(0)$ & $14.64 \mathrm{a}$ & $17.55 \mathrm{a}$ & $1.14 \mathrm{a}$ \\
\hline Moderate (2.5) & $20.47 \mathrm{a}$ & $16.92 \mathrm{a}$ & $1.23 \mathrm{a}$ \\
\hline High (5) & $18.33 \mathrm{a}$ & $17.40 \mathrm{a}$ & $1.25 \mathrm{a}$ \\
\hline Interaction & $(-)$ & $(-)$ & $(-)$ \\
\hline$\overline{\mathrm{CV} \%}$ & 10.43 & 5.92 & 26.43 \\
\hline
\end{tabular}

Remarks: The values followed by the same letter were not different from DMRT 5\%

Table 4. Correlation Coefficient among Parameters

\begin{tabular}{|c|c|c|c|c|c|}
\hline & PH_9MST & SD_9MST & NPP & W100grain & Yield \\
\hline PH_9MST & 1 & & & & \\
\hline SD_9MST & $0.206^{\mathrm{ns}}$ & 1 & & & \\
\hline JPpT & $0.151^{\mathrm{ns}}$ & $0.46^{* *}$ & 1 & & \\
\hline B100B & $-0.007^{\mathrm{ns}}$ & $0.270^{\mathrm{ns}}$ & $-0.121^{\mathrm{ns}}$ & 1 & \\
\hline Crops & $0.506^{* *}$ & $0.303^{*}$ & $0.313^{*}$ & $0.112^{\mathrm{ns}}$ & 1 \\
\hline
\end{tabular}


a positive correlation between seed yield and pods $\left(\mathrm{r}=0.87^{* *}\right)$.

\section{CONCLUSION}

There was no interaction between fertilizer and mycorrhizal application on growth parameters and yield parameters of soybean cultivated among eucalyptus stands. The use of compound fertilizer with usual doses given by farmers of 45-45-45 kg/ha did not increase the seed yield of soybean compared with those without fertilization. The substitution of compound fertilizer with single fertilizer of Urea, SP-36, and $\mathrm{KCl}$ with similar doses that were usually given by farmers for compound fertilizers could increase the seed yield when compared to those without fertilization and the use of compound fertilizers by farmers. The substitution of compound fertilizer with single fertilizer of Urea, SP-36, and $\mathrm{KCl}$ in a low dose (2336-30) did not increase the seed yield compared to those without fertilization. The seed yield increased when the high doses fertilizer were given (23-10890 ). The highest seed yield of $1.49 \mathrm{t} / \mathrm{ha}$ was obtained with the high dose of single fertilizer, but it was not significantly different from the seed yield of a single fertilizer given by farmers, i.e. $1.37 \mathrm{t} / \mathrm{ha}$. The high level of seed yield was achieved because the plants formed many pods but not larger seeds.

\section{ACKNOWLEDGEMENT}

The author thanks to Jaka Widada, Ph.D. and colleagues for their great contributions.

\section{REFERENCES}

Aldeman, J. M. and J.B. Morton. 1986. Infectivity of Vesicular-Arbuscular Mychorrizal Fungi Influence Host Soil Diluents Combination on MPN Estimates and Percentage Colonization. Soil Biolchen. 8(1): 77-83.

Aziz, A. L. A., B. D. K. Ahiabor, A. Opoku and R. C. Abaidoo. 2016. Contributions of Rhizobium Inoculants and Phosphorus Fertilizer to Biological Nitrogen Fixation, Growth and Grain Yield of Three Soybean Varieties on a Fluvic Luvisol, 10(2): 1-11.

Cram, M. M. and R.K. Dumroese. 2012. Mycorrhizae in Forest Tree Nurseries. Forest Nursery Pests. United States Department of Agriculture, pp.1-212.

Da-yong, L., Z. Zhi-an, Z. Dian-jun, J. Li-yan and W. Yuan-li. 2012. Comparison of Net Photosynthetic Rate in Leaves of Soybean with Different Yield Levels. Journal of Northeast Agricultural University (English Edition).
19(3):14-19.

Guissou, T. 2009. Contribution of Arbuscular Mycorrhizal Fungi to Growth and Nutrient Uptake by Jujube and Tamarind Seedlings in a Phosphate (P). Deficient Soil. 3(5): 297-304.

Mandal, K. G., K. M. Hati, , and A. K, Misra, . 2009. Biomass Yield and Energy Analysis of Soybean Production in Relation to Fertilizer-NPK and Organic Manure. Biomass and Bioenergy. 33(12): 1670-1679.

Mete, F. Z. S. Mia., F.A. Dijkstra., M. Abuyusuf and A.S.M.I. Hossain. 2015. Synergistic Effects of Biochar and NPK Fertilizer on Soybean Yield in an Alkaline Soil. Pedosphere. 25(5): 713-719.

Muis, A. D. Indradewa., J. Widada. 2013. Pengaruh Inokulasi Mikoriza Arbuskula Terhadap Pertumbuhan dan Hasil Kedelai (Glycine max (L.) Merrill) pada berbagai Interval Penyiraman. Vegetalika. 2(2): 7-20.

Oktaviani, D., Y. Hasanah., and A. Barus. 2014. Pertumbuhan Kedelai (Glycine max L. Merrill) dengan Aplikasi Fungi Mikoriza Arbuskular (FMA) dan Konsorsium Mikroba. Jurnal Online Agroekoteknologi. 2(2): 905- 918.

Simanungkalit. 2001. Aplikasi Pupuk Hayati dan Pupuk Kimia: Suatu Pendekatan Terpadu. Buletin Agrobio. 4(2): 56-61.

Sirappa, M. P. and A.J. Rieuwpassa. 2010. Keragaan dan Potensi Hasil Beberapa Varietas Padi pada Lahan Sawah Bukaan Baru di Seram Utara Maluku Tengah. Jurnal Budidaya Pertanian. 6(2): 84-94.

Sudarmaji., R. Kaliky., Gunawan., S. Rustijarno., S.B. Lestari. 2013. 100 Inovasi Teknologi Pertanian Spesifik Lokasi Daerah Istimewa Yogyakarta. Badan Penelitian dan Pengembangan Pertanian. pp.1-121.

Suryanto., P. Tohari and M.S. Sabarnurdin. 2005. Dinamika Sistem Berbagi Sumberdaya (Resouces Sharing) dalam Agroforestri: Dasar Pertimbangan Penyusunan Strategi Silvikultur. Ilmu Pertanian. 12(2):.165-178

Wangiyana, W., M. Sitorus and H. Abdurrachman. 2007. Respon Tanaman Kedelai Terhadap Inokulasi dengan Fungi Mikoriza Arbuskular dan Aplikasi Pupuk Daun Organik "Greenstant”. Agroteksos.17(3): 157-166. 